\title{
PENGARUH PERENDAMAN BIJI KAKAO KERING DAN BAHAN ALAT SANGRAI TERHADAP SIFAT FISIK DAN PROFIL SENYAWA VOLATIL KAKAO SANGRAI SERTA SIFAT SENSORIS COKELAT BATANG YANG DIHASILKAN
}

\author{
Effect of Dry Bean Soaking and Roasting Instrument Material on Physical Properties, Volatile Compound Profile \\ of Roasted Cocoa and Chocolate Bar Sensory Attributes
}

Yulius Gae Lada, Supriyanto, Purnama Darmadji

\author{
Program Studi Teknologi Hasil Perkebunan, Fakultas Teknologi Pertanian, Universitas Gadjah Mada, \\ Jl. Flora No. 1, Bulaksumur, Yogyakarta 55281 \\ Email: juliusdacosta89@gmail.com
}

\begin{abstract}
ABSTRAK
Penelitian ini bertujuan untuk mengetahui pengaruh perendaman biji kakao kering dan penyangraian menggunakan berbagai jenis bahan alat sangrai terhadap sifat fisik dan profil senyawa volatil kakao sangrai serta sifat sensoris cokelat batang yang dihasilkan. Biji kakao kering direndam menggunakan air selama 2 jam untuk mengurangi keasaman, kemudian disangrai menggunakan berbagai jenis bahan alat sangrai (alumunium, besi dan tanah liat) hingga kadar air biji kakao sangrai mencapai $2-3,5 \%$. Biji kakao kering diamati dan dianalisis sifat fisik dan profil senyawa volatil biji kakao sangrai serta sifat sensoris cokelat batang. Hasil penelitian menunjukkan bahwa penggunaan alat sangrai dari tanah liat lebih cepat dalam mematangkan biji kakao kering menjadi biji sangrai (50 menit) dengan laju peningkatan suhu yang cepat dan tinggi, selanjutnya diikuti dengan alat sangrai yang terbuat dari besi (70 menit) dan alumunium (90 menit). Perlakuan perendaman biji kakao kering berpengaruh nyata terhadap warna biji sangrai (nilai L* dan E) dan sifat sensoris cokelat batang yang dihasilkan terutama aroma cokelat, rasa asam dan pahit, sedangkan perlakuan bahan alat sangrai tidak berpengaruh nyata. Tekstur biji kakao dari hasil penyangraian menggunakan alat sangrai dari alumunium adalah paling keras, tetapi tidak dipengaruhi oleh perlakuan perendaman. Penyangraian biji kakao menggunakan alat sangrai dari alumunium, besi dan tanah liat menghasilkan profil senyawa volatil yang berbeda. Dari kromatogram SPME-GC-MS diketahui bahwa alat sangrai dari tanah liat menghasilkan kelompok senyawa dan total luas area yang lebih kecil dibandingkan dengan alat sangrai dari alumunium dan besi. Cokelat batang yang dihasilkan melalui perendaman dan disangrai menggunakan alat sangrai dari tanah liat adalah yang paling disukai oleh panelis.
\end{abstract}

Kata kunci: Perendaman, bahan alat sangrai, biji kakao sangrai, profil senyawa volatil, cokelat batang

\begin{abstract}
This research aimed at evaluating the effect of dry cocoa bean soaking and roasting using various type of materials roaster instrument on the physical properties and profile of volatile compounds of roasted beans as well as sensorial attributes of chocolate bar resulted. Dry beans were soaked into water for $2 \mathrm{~h}$ to reduce acidity. Roasting was carried out using several instruments that were made from aluminum, iron and clay to obtain bean moisture content of $2-3.5 \%$. Texture, color, and volatile compounds profile of roasted beans as well as sensorial attributes of chocolate bar were studied. Results showed that roasting cooking period (50 minutes) using clay roasting instrument was faster and had highest rate of temperature increase, followed by iron (70 minutes) and aluminum ( 90 minutes). Dry beans soaking significantly affected beans color ( $\mathrm{L}^{*}$ and E value), chocolate bar attributes particularly aroma, acid taste and bitterness, however the instrument material differences had no significant effect on those parameters. The texture of cocoa beans roasted using a roaster of aluminum was the hardest, but it was not affected by the soaking treatment. Roasting of the cocoa beans using a roaster of aluminum, iron and clay produced different profiles on volatile compounds. A roaster of clay produced groups of compounds with the total area of SPME-GC-MS chromatogram was smaller than the roaster of aluminum and iron. The produced chocolate bars through the soaking treatment and roasting using a roaster of clay was preferred by the panelists.
\end{abstract}

Keywords: Soaking, materials of roaster instrument, roasted cocoa beans, volatile compounds profile, chocolate bar 


\section{PENDAHULUAN}

Kakao merupakan salah satu komoditas andalan perkebunan yang memegang peranan cukup penting dalam perekonomian Indonesia. Sebagian besar produksi kakao dari Indonesia diekspor karena pembayarannya lebih cepat dibandingkan mengolah biji kakao tersebut menjadi produk olahan kakao yang mempunyai nilai tambah yang lebih tinggi. Salah satu produk olahan kakao yang sangat diminati oleh para konsumen adalah cokelat batang. Umumnya proses pengolahan biji kakao kering menjadi cokelat batang meliputi penyangraian, pemisahan nib dari kulit biji, penghalusan, pencampuran (penambahan beberapa bahan-bahan seperti gula halus, lemak sawit/lemak kakao, lesitin serta bahan lainnya), penggilasan serta tempering (Setiavani, 2012). Di beberapa industri besar, pengolahan biji kakao kering menjadi cokelat batang menggunakan peralatan dan mesin yang canggih dan mahal. Penggunaan peralatan dan mesin tersebut, menjadi permasalahan yang cukup sulit jika diterapkan kepada para petani kakao, maka salah satu alternatif terbaik adalah dengan memperkenalkan penggunaan peralatan sederhana berbasis rumah tangga.

Biji kakao kering hasil fermentasi di Indonesia umumnya memiliki kadar keasaman yang tinggi. Kadar keasaman $(\mathrm{pH})$ pada biji kakao sangat berpengaruh pada kualitas dan kuantitas komponen-komponen aroma yang dihasilkan selama proses penyangraian yang didapatkan setelah proses fermentasi. Diketahui pada $\mathrm{pH}$ yang mendekati netral $(\mathrm{pH}>5,2)$ senyawasenyawa aroma khas cokelat terbentuk secara intensif, sedangkan pada $\mathrm{pH}$ yang rendah $(\mathrm{pH}<5,2)$ pembentukan aroma khas cokelat terbatas (Nadlirah, 2007). Jika kadar keasaman yang tinggi tersebut tidak dihilangkan, maka akan mengakibatkan rendahnya mutu biji kakao kering yang juga akan berpengaruh pada cokelat batang yang dihasilkan. Salah satu metode sederhana dan efisien yang dapat menghilangkan kadar keasaman pada biji kakao kering adalah dengan cara perendaman.

Selain perendaman, proses lain yang juga sangat berperan dalam pembentukan flavour pada produk kakao adalah proses roasting atau penyangraian. Penyangraian merupakan salah satu tahapan penting yang bertujuan untuk membentuk aroma dan cita rasa khas cokelat dari biji kakao serta untuk mempermudah mengeluarkan lemak dari dalam biji (Nanti, 2008). Dua senyawa yang sangat berperan penting membentuk aroma dan cita rasa khas cokelat dalam penyangraian adalah gula reduksi dan asam amino. Selain itu, kesempurnaan reaksi penyangraian juga sangat dipengaruhi oleh panas, waktu, dan kadar air (Setiavani, 2012). Faktor penting yang mempengaruhi proses penyangraian dalam pengolahan biji kakao menjadi cokelat batang berskala rumah tangga adalah penggunaan bahan alat sangrai dalam proses penyangraian tersebut, yang juga akan mempengaruhi lamanya waktu penyangraian dan suhu penyangraian. Umumnya dengan menggunakan alat sangrai yang terbuat dari alumunium, besi atau sejenisnya dapat mempercepat proses penyangraian, karena transfer panas berlangsung lebih cepat. Sedangkan penggunaan alat sangrai yang terbuat dari tanah liat, diduga proses transfer panas berlangsung sangat lambat karena memiliki sifat konduktifitas yang rendah.

Tujuan dari penelitian ini adalah mengetahui pengaruh perendaman biji kakao kering dan bahan alat sangrai (alumunium, besi dan tanah liat) terhadap sifat fisik dan profil senyawa volatil kakao sangrai serta sifat sensoris cokelat batang yang dihasilkan.

\section{METODE PENELITIAN}

\section{Bahan}

Bahan baku adalah biji kakao kering fermentasi varietas Lindak yang diperoleh dari PT. Pagilaran. Bahan yang digunakan untuk membuat cokelat batang meliputi lemak kakao diperoleh dari Pusat Penelitian Kopi dan Kakao Jember, gula halus dan lesitin diperoleh dari toko roti Intisari, Yogyakarta.

\section{Alat}

Alat penyangrai yang digunakan antara lain alat sangrai yang terbuat dari alumunium (diameter $37 \mathrm{~cm}$ dan ketebalan $0,5 \mathrm{~cm}$ ), alat sangrai yang terbuat dari besi (diameter 37,5 $\mathrm{cm}$ dan ketebalan $0,5 \mathrm{~cm}$ ), dan alat sangrai yang terbuat dari tanah liat (diameter $30 \mathrm{~cm}$ dan ketebalan $1 \mathrm{~cm}$ ).

\section{Perlakuan Perendaman Biji Kakao}

Sebanyak 0,5 kg biji kakao kering yang telah terfermentasi sempurna dilakukan perendaman menggunakan air selama 2 jam dengan perbandingan biji kakao dengan air adalah $1: 3,5$ hingga semua biji terendam (Purwandaru, 2013). Kemudian biji kakao kering hasil perendaman tersebut ditiriskan dan dilakukan pengeringan kembali dengan menggunakan cabinet dryer selama 24 jam, selanjutnya dikering-anginkan semalaman.

\section{Penyangraian Biji Kakao}

Biji kakao kering sebanyak $0,5 \mathrm{~kg}$ baik yang telah dilakukan perendaman atau tanpa perendaman, dimasukkan ke dalam alat sangrai. Kemudian diletakkan di atas kompor listrik, di nyalakan pada tegangan 300 watt. Selama penyangraian berlangsung dilakukan pengadukan agar biji kakao tidak menjadi gosong, dan dilakukan pengukuran suhu setiap selang waktu 5 menit, meliputi suhu di antara biji kakao yang disangrai dan suhu permukaan alat sangrai (di ukur 
tepat di tengah dasar alat) menggunakan thermocouple yang dilengkapi dengan seperangkat data logger dan komputer. Peralatan yang digunakan untuk penyangraian adalah seperti pada Gambar 1.

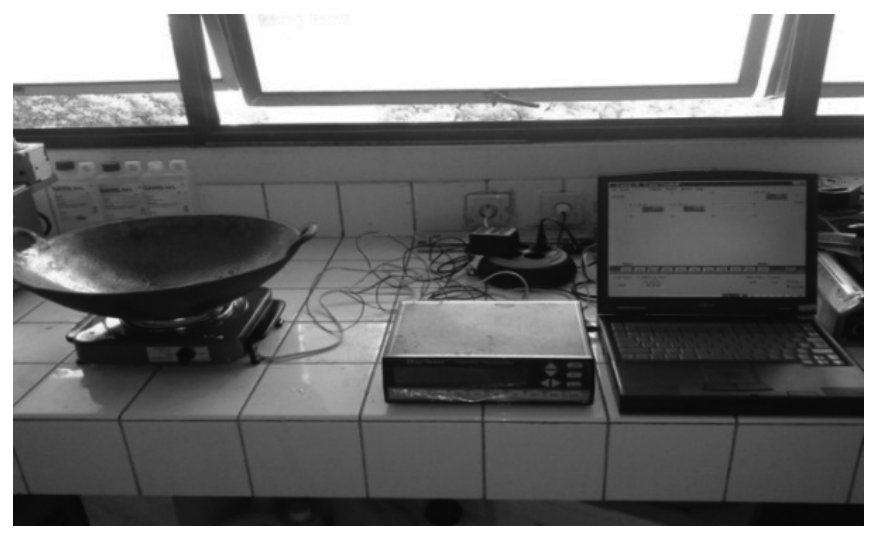

Gambar 1. Perangkat alat untuk mengukur suhu yang terdiri dari data logger 8 channel dan komputer.

Pada saat pengukuran suhu permukaan bahan dan permukaan alat sangrai berlangsung, pengadukan dihentikan sementara waktu selama 15 detik hingga suhu dibaca pada data logger kemudian pengadukan dilanjutkan kembali agar biji kakao tidak menjadi gosong. Penyangraian pada tegangan 300 watt berlangsung selama 30 menit, setelah itu tegangan dinaikkan menjadi 600 watt, sampai biji menjadi matang yang ditandai dengan aroma harum cokelat, kulit biji terlihat retak dan pecah, warna kulit biji menjadi agak pucat serta kadar air biji mencapai 2 - 3,5\%. Setelah biji kakao matang, penyangraian dihentikan. Cara pengukuran suhu permukaan bahan dan suhu pada alat sangrai ditampilkan pada Gambar 2.

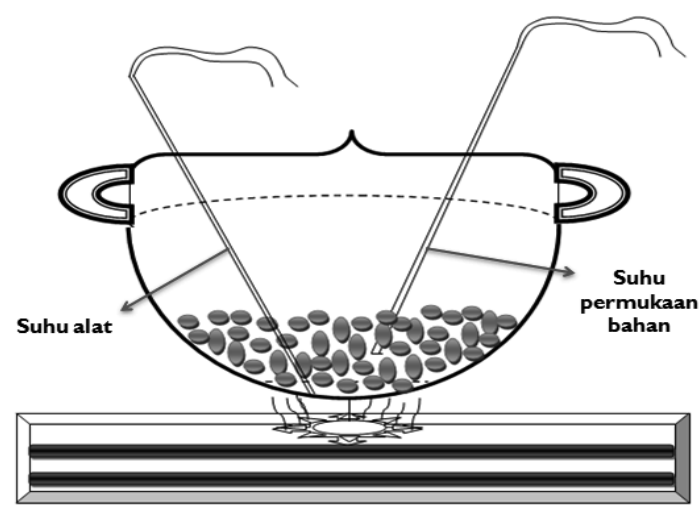

Gambar 2. Cara pengukuran suhu permukaan bahan dan suhu pada alat sangrai

\section{Pembuatan Cokelat Batang}

Biji kakao kering yang telah disangrai dipisahkan dari kulit bijinya secara manual dengan menggunakan tangan, sehingga diperoleh kotiledon bebas kulit atau yang disebut nib. Nib biji kakao digiling selama 2 jam menggunakan penggiling daging yang dipanaskan dengan hembusan udara panas dari hair dryer sampai berbentuk pasta (liquor). Selanjutnya, pasta kakao dimasukkan ke dalam ball mill yang berisi bola-bola besi dengan perbandingan pasta kakao : bola- bola besi yaitu $1: 4$. Selama penghalusan berlangsung, dilakukan penambahan lemak kakao (30\%), gula halus $(40 \%)$ dan lesitin $(0,5 \%)$. Setelah proses penghalusan selama $\pm 2,5$ jam, adonan cokelat telah tercampur merata, kemudian dilakukan proses tempering, dengan cara sebagai berikut: adonan yang dikeluarkan dari ball mill, suhunya diturunkan secara cepat dari $50^{\circ} \mathrm{C}$ menjadi $27^{\circ} \mathrm{C}$ sambil dilakukan pengadukan selanjutnya suhu adonan dinaikkan kembali hingga mencapai suhu $30^{\circ} \mathrm{C}$ sambil dilakukan pengadukan. Setelah tercapai suhu $30^{\circ} \mathrm{C}$, dilakukan pencetakan dan selanjutnya dilakukan pendinginan.

\section{Pengujian Tekstur, Warna, Senyawa Volatil dan Sensoris}

Tekstur biji kakao sangrai, menggunakan Unit Testing Machine (UTM). Warna dan ketampakan biji kakao sangrai, menggunakan Chromameter MINOLTA CR-400. (Apriyanto,1989). Profil senyawa volatil menggunakan metode SPME- GC-MS (Afoakwa, dkk., 2009). Uji sensoris menggunakan metode scoring (Misnawi dkk., 2004). Pada uji sensoris tersebut untuk atribut aroma cokelat, atribut rasa (asam, sepat, pahit) dan analisis tingkat kesukaan pada cokelat batang yang dihasilkan. Skala penilaian atribut sensoris untuk cokelat batang (rasa asam/sepat/pahit dan aroma cokelat): 1 = amat sangat lemah; 2 = sangat lemah; $3=$ lemah; $4=$ agak lemah; $5=$ cukup kuat; $6=$ kuat; $7=$ sangat kuat; $8=$ amat sangat kuat. Sedangkan skala penilaian kesukaan: $1=$ paling disukai hingga $6=$ paling tidak disukai.

\section{Rancangan Penelitian}

Rancangan Penelitian yang digunakan dalam penelitian ini adalah Rancangan Acak Kelompok, percobaan faktorial. Faktor perlakuan yang diberikan dalam penelitian ini adalah perlakuan perendaman dan tanpa perendaman biji kakao kering serta perlakuan penggunaan bahan alat sangrai yaitu alumunium, besi dan tanah liat. Pengaruh yang berbeda nyata selanjutnya diuji dengan uji $\mathrm{T}$ (T-test) pada $\mathrm{p} \leq 0,05$ untuk perlakuan perendaman dan tanpa perendaman sedangkan Duncan's Multiple Range Test (DMRT) pada $\mathrm{p} \leq 0,05$ untuk perlakuan penggunaan bahan alat sangrai.

\section{HASIL DAN PEMBAHASAN}

\section{Waktu Pematangan Biji Kakao Sangrai}

Hasil penelitian menunjukkan bahwa perlakuan perendaman tidak memberikan pengaruh terhadap waktu yang diperlukan untuk mematangkan biji kakao kering 
menjadi biji sangrai sedangkan pada perlakuan penyangraian menggunakan berbagai jenis bahan alat sangrai (alumunium, besi dan tanah liat) memberikan pengaruh yang berbeda $(p<0,05)$ terhadap waktu yang diperlukan untuk mematangkan biji kakao kering menjadi biji sangrai. Hal ini ditunjukkan pada laju peningkatan suhu permukaan bahan (biji kakao) dan alat sangrai yang digunakan.

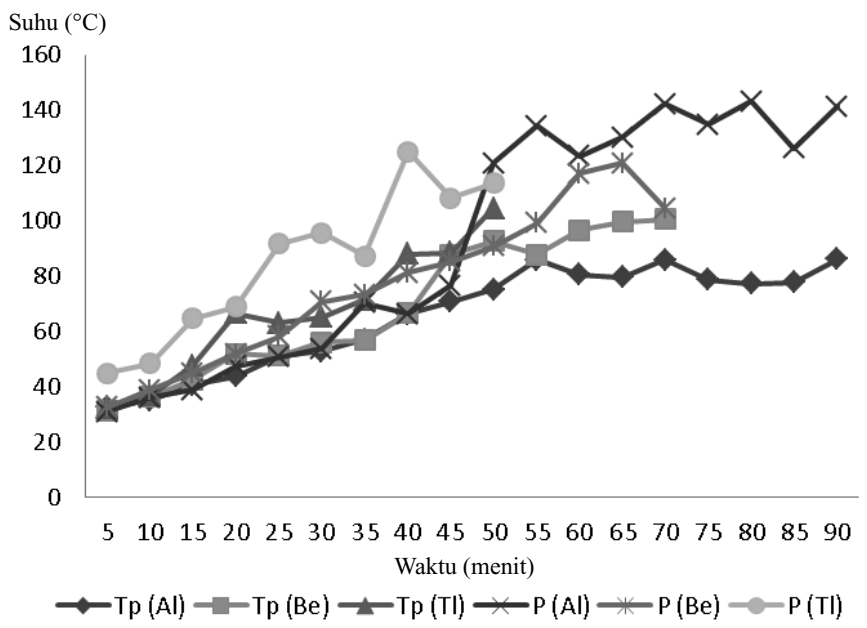

Keterangan: $\mathrm{Tp}(\mathrm{Al})=$ Tanpa perendaman, Alumunium; $\mathrm{Tp}(\mathrm{Be})=$ Tanpa perendaman,Besi; $\mathrm{Tp}(\mathrm{Tl})=$ Tanpa perendaman,Tanah liat; $\mathrm{P}(\mathrm{Al})=$ Perendaman,Alumunium; $\mathrm{P}(\mathrm{Be})=$ Perendaman, Besi; $\mathrm{P}(\mathrm{Tl})=$ Perendaman, Tanah liat

Gambar 3. Suhu permukaan bahan dengan perlakuan perendaman dan tanpa perendaman biji kakao kering pada berbagai jenis bahan alat sangrai

Pada Gambar 3 terlihat bahwa penyangraian menggunakan alat sangrai yang terbuat dari tanah liat memberikan waktu tercepat yaitu selama 50 menit untuk mematangkan biji kakao kering menjadi biji sangrai hingga mencapai kadar air biji sangrai sekitar $2-3,5 \%$. Sedangkan penyangraian menggunakan alat sangrai yang terbuat dari besi, memerlukan waktu untuk mematangkan biji kakao kering menjadi biji sangrai selama 70 menit dan penyangraian menggunakan alat sangrai dari alumunium memerlukan waktu yang lebih lama yaitu 90 menit. Hal tersebut menunjukkan bahwa alat sangrai yang terbuat dari tanah liat dapat menghantarkan panas lebih cepat, mungkin disebabkan karena sifat tanah liat yang porous hingga penghantaran panas dari sumber panas kepada bahan yang disangrai berlangsung secara konveksi oleh udara panas yang melalui pori-pori tersebut. Pendapat tersebut sejalan dengan Rohmi dkk. (2013), yang menyatakan bahwa alat sangrai dari tanah liat memiliki sifat penghantar panas yang porous (berpori-pori) sehingga aliran panas yang dihantarkan ke bahan dapat secara langsung diterima oleh bahan karena sifat porous tersebut.

\section{Tekstur Biji Kakao Sangrai}

Berdasarkan hasil analisis statistik perlakuan perendaman dan tanpa perendaman biji kakao kering tidak berpengaruh nyata pada tekstur biji kakao sangrai. Hal ini disebabkan karena biji kakao kering dengan perlakuan perendaman ataupun tanpa perlakuan perendaman sebelum dilakukan penyangraian memiliki kadar air yang sama sekitar 6 - 7\% sehingga setelah disangrai, tekstur biji baik dengan perlakuan perendaman maupun tanpa perendaman memberikan tekstur yang rapuh (fraktur). Setelah dilakukan perendaman, biji akan dikeringkan kembali di dalam cabinet dryer selama 24 jam sebelum dilakukan penyangraian.

Pada faktor perlakuan penggunaan berbagai jenis bahan alat sangrai, hasil analisis statistik menunjukkan bahwa faktor perlakuan tersebut tidak berpengaruh nyata. Namun, jika dilihat dari rata-rata yang dihasilkan pada Tabel 1 menunjukkan bahwa tekstur biji sangrai dengan penyangraian menggunakan alat sangrai dari alumunium, memberikan nilai rata-rata yang lebih tinggi dibandingkan tekstur biji sangrai yang dihasilkan dengan penyangraian menggunakan alat sangrai dari besi dan tanah liat. Hal ini disebabkan oleh panas yang dihasilkan dari jenis alat sangrai yang digunakan. Sumber panas yang berasal dari kompor listrik dan kemudian secara konduksi diteruskan dengan merata ke seluruh bagian pada alat sangrai dari alumunium, dihasilkan suhu bahan yang rendah yaitu $86,1^{\circ} \mathrm{C}$, dan tekstur biji sangrai yang dihasilkan memiliki nilai

Tabel 1. Tekstur biji sangrai $(\mathrm{N})$ dengan perlakuan perendaman dan tanpa perendaman biji kakao kering serta penggunaan berbagai jenis bahan alat sangrai.

\begin{tabular}{|c|c|c|c|c|}
\hline \multirow{2}{*}{ Perlakuan } & \multicolumn{3}{|c|}{ Tekstur biji sangrai $(\mathrm{N})$} & \multirow{2}{*}{ Rata-rata statistik } \\
\hline & Alumunium (Al) & Besi $(\mathrm{Be})$ & Tanah liat $(\mathrm{Tl})$ & \\
\hline Perendaman $(\mathrm{P})$ & $26,69 \pm 8,57^{b}$ & $33,19 \pm 1,77^{b}$ & $15,85 \pm 1,49^{c}$ & $21,89 \pm 9,25^{x}$ \\
\hline Tanpa perendaman (TP) & $67,24 \pm 10,76^{a}$ & $11,68 \pm 0,78^{\mathrm{c}}$ & $14,01 \pm 3,88^{\mathrm{c}}$ & $30,98 \pm 27,82^{x}$ \\
\hline Rata-rata statistik & $44,76 \pm 26,90^{\mathrm{k}}$ & $20,33 \pm 9,59^{1}$ & $14,22 \pm 2,65^{1}$ & \\
\hline
\end{tabular}

Keterangan :

- Huruf superskrip yang sama pada baris yang sama menyatakan tidak beda nyata pada tingkat signifikansi 95\%.

- Pada rata-rata statistik, huruf superskrip yang sama pada kolom yang sama dan pada baris yang sama menyatakan tidak beda nyata pada tingkat signifikansi $95 \%$. 
tekstur yang lebih tinggi atau tidak rapuh. Sementara itu pada penyangraian dengan menggunakan alat sangrai dari besi dan tanah liat menghasilkan biji kakao sangrai dengan suhu yang lebih tinggi masing-masing $100,5^{\circ} \mathrm{C}$ dan $104,4^{\circ} \mathrm{C}$ sehingga nilai tekstur biji sangrai yang dihasilkan pada kedua jenis alat sangrai ini lebih rendah atau bersifat lebih rapuh.

\section{Warna Biji Kakao Sangrai $\left(L^{*}\right.$ dan $\left.\Delta E\right)$}

Berdasarkan hasil perhitungan statistik pada nilai $\mathrm{L}^{*}$, faktor perlakuan perendaman dan tanpa perendaman biji kakao kering berpengaruh nyata terhadap nilai $\mathrm{L}^{*}$ (kecerahan). Hal ini terlihat pada Tabel 2 (a) yang menunjukkan bahwa biji kakao sangrai dengan perlakuan perendaman memberikan nilai L* (kecerahan) yang lebih rendah atau sedikit gelap bila dibandingkan dengan biji kakao sangrai tanpa perlakuan perendaman yang memberikan nilai $L^{*}$ (kecerahan) yang lebih tinggi. Hal ini mungkin disebabkan oleh keberadaan senyawa tanin dalam biji kakao yang dapat larut didalam air dan bereaksi dengan ion Fe yang terdapat bebas di dalam air pada saat perendaman sehingga menghasilkan warna yang gelap (Risfaheri dkk., 2005). Sedangkan pada faktor perlakuan penggunaan berbagai jenis bahan alat sangrai, tidak memberikan pengaruh yang berbeda nyata.

Analisis $\Delta \mathrm{E}$ pada warna biji kakao sangrai bertujuan untuk mengetahui perbedaan/perubahan warna biji kakao sangrai antara 2 faktor perlakuan yang diberikan yaitu faktor perlakuan perendaman biji kakao kering dan faktor penggunaan berbagai jenis bahan alat sangrai. Nilai $\Delta \mathrm{E}$ didapatkan dengan perhitungan menggunakan rumus:

$$
\Delta E_{a b}^{*}=\sqrt{\left(L_{2}^{*}-L_{1}^{*}\right)^{2}+\left(a_{2}^{*}-a_{1}^{*}\right)^{2}+\left(b_{2}^{*}-b_{1}^{*}\right)^{2}}
$$

Kriteria perbedaan/perubahan warna pada $\Delta \mathrm{E}$ antara lain jika perbedaan/perubahan warna yang terjadi $<0,2$ (pengaruhnya tidak terlihat), 0,2 - 1,0 (pengaruhnya sangat kecil), 1,0 - 3,0 (pengaruhnya kecil), 3,0 - 6,0 (pengaruhnya sedang) sedangkan $>6,0$ (pengaruh yang besar). Pada Tabel 2 (b) memperlihatkan perbedaan/perubahan warna pada biji kakao sangrai dari 2 faktor perlakuan yang diberikan. Hasil analisis statistik menunjukkan bahwa faktor perlakuan perendaman dan tanpa perendaman biji kakao kering memberikan pengaruh yang berbeda nyata. Sedangkan hasil analisis statistik untuk perlakuan penggunaan berbagai jenis bahan alat sangrai, tidak memberikan pengaruh yang berbeda nyata. Pada perlakuan perendaman dan tanpa perendaman biji kakao kering untuk penyangraian menggunakan semua bahan alat sangrai (alumunium, besi, dan tanah liat), perbedaan/ perubahan nilai $\Delta \mathrm{E}$ yang terjadi adalah kecil yaitu $(1,0-3,0)$.

\section{Profil Senyawa Volatil}

Jumlah senyawa volatil yang dihasilkan pada biji kakao sangrai menggunakan alat sangrai dari alumunium berjumlah 63 senyawa sedangkan alat sangrai dari besi dan tanah liat berjumlah 58 senyawa. Berdasarkan Tabel 3, total luas area dari senyawa volatil pada biji kakao sangrai dengan menggunakan alat sangrai dari alumunium adalah paling tinggi, diikuti dengan total luas area dari senyawa volatil biji kakao sangrai menggunakan alat sangrai dari besi dan terendah adalah total luas area senyawa volatil biji kakao menggunakan alat sangrai dari tanah liat, masing-masing dengan perbandingan luas $140: 158$ dan 113. Pemilihan luas area sebagai respon didasarkan pada Fardias (1989) dalam Febrianto (2009), yang menyatakan bahwa ukuran puncak

Tabel 2. (a) Nilai $L^{*}$ dan (b) Nilai $\Delta \mathrm{E}$ pada biji sangrai dengan perlakuan perendaman dan tanpa perendaman biji kakao kering serta penggunaan berbagai jenis bahan alat sangrai

\begin{tabular}{|c|c|c|c|c|}
\hline \multicolumn{5}{|c|}{ Nilai L } \\
\hline \multirow{2}{*}{ Perlakuan } & \multicolumn{3}{|c|}{ Bahan alat sangrai } & \multirow{2}{*}{ Rata-rata statistik } \\
\hline & Alumunium (Al) & Besi (Be) & Tanah liat $(\mathrm{Tl})$ & \\
\hline Perendaman $(\mathrm{P})$ & $32,29 \pm 1,57^{\mathrm{d}}$ & $33,51 \pm 0,89^{\mathrm{cd}}$ & $34,22 \pm 0,94^{\mathrm{c}}$ & $33,34 \pm 1,36^{x}$ \\
\hline Tanpa perendaman (TP) & $38,84 \pm 0,41^{\mathrm{b}}$ & $40,12 \pm 1,40^{\mathrm{ab}}$ & $40,34 \pm 0,85^{\mathrm{a}}$ & $39,77 \pm 1,13^{\mathrm{y}}$ \\
\hline Rata-rata statistik & $35,57 \pm 3,61^{\mathrm{k}}$ & $36,82 \pm 3,65^{\mathrm{k}}$ & $37,28 \pm 3,33^{\mathrm{k}}$ & \\
\hline \multicolumn{5}{|c|}{ Nilai $\Delta \mathrm{E}$} \\
\hline \multirow{2}{*}{ Perlakuan } & \multicolumn{3}{|c|}{ Bahan alat sangrai } & \multirow{2}{*}{ Rata-rata statistik } \\
\hline & Alumunium (Al) & Besi (Be) & Tanah liat (Tl) & \\
\hline Perendaman $(\mathrm{P})$ & $4,69 \pm 1,18^{\mathrm{a}}$ & $2,21 \pm 0,55^{b}$ & $1,87 \pm 1,01^{\mathrm{b}}$ & $2,92 \pm 1,57^{x}$ \\
\hline Tanpa perendaman (TP) & $3,18 \pm 1,13^{b}$ & $5,61 \pm 1,04^{\mathrm{a}}$ & $4,93 \pm 1,43^{\mathrm{a}}$ & $4,57 \pm 1,54^{y}$ \\
\hline Rata-rata statistik & $3,94 \pm 1,35^{\mathrm{k}}$ & $3,91 \pm 1,96^{\mathrm{k}}$ & $3,39 \pm 1,99^{k}$ & \\
\hline
\end{tabular}

\section{Keterangan :}

- Huruf superskrip yang sama pada baris yang sama menyatakan tidak beda nyata pada tingkat signifikansi 95\%.

- Pada rata-rata statistik, huruf superskrip yang sama pada kolom yang sama dan pada baris yang sama menyatakan tidak beda nyata pada tingkat signifikansi $95 \%$. 
kromatogram sebanding dengan jumlah komponen yang menyebabkan puncak itu terbentuk. Hal ini menunjukkan bahwa waktu dan suhu penyangraian merupakan faktor utama yang berperan penting dalam pembentukan senyawa-senyawa volatil pada biji kakao sangrai.

Tabel 3. Hasil dan luas area senyawa volatil pada biji kakao sangrai tanpa perlakuan perendaman biji kakao kering dengan penyangraian menggunakan berbagai jenis alat sangrai.

\begin{tabular}{|c|c|c|c|}
\hline \multirow{2}{*}{$\begin{array}{l}\text { Komponen } \\
\text { PIRAZIN }\end{array}$} & \multicolumn{2}{|c|}{ Area } & \multirow[b]{2}{*}{ A. Tanah liat } \\
\hline & A. Alumunium & A. Besi & \\
\hline Pyrazine, methyl- & 549757 & 169210 & 578108 \\
\hline pyrazine, 2,5-dimethyl- & 618949 & 253302 & 359888 \\
\hline Pyrazine, 2,3-dimethyl- & 604819 & 730132 & 469103 \\
\hline Pyrazine, 2-ethyl-5-methyl- & 370559 & 543494 & 346030 \\
\hline Pyrazine, 2-ethyl-3-methyl- & 395277 & 721080 & 404074 \\
\hline Pyrazine, trimethyl- & 1618650 & 2228731 & 992950 \\
\hline 2,3-Dimethyl-5-ethylpyrazine & 231987 & 270170 & 108109 \\
\hline Pyrazine, tetramethyl- & 5992475 & 7660200 & 3654039 \\
\hline $\begin{array}{l}\text { 2,3,5-Trimethyl-6- } \\
\text { ethylpyrazine }\end{array}$ & 178269 & 230143 & 72210 \\
\hline Pyrazine, ethyl- & 92582 & 6756 & 34611 \\
\hline Pyrazine, 2,6-dimethyl- & $\operatorname{ttd}$ & 4543 & ttd \\
\hline Pyrazine, 3-ethyl-2,5-dimethyl- & $\operatorname{ttd}$ & $\mathrm{ttd}$ & 311925 \\
\hline Pyrazine, 2-ethyl-6-methyl- & 576104 & ttd & ttd \\
\hline Total & 11.229.428 & 12.817 .761 & 7.331.047 \\
\hline \multicolumn{4}{|l|}{ ESTER } \\
\hline 1-Butanol, 3-methyl-, acetate & 314148 & 460931 & ttd \\
\hline Octanoic acid, ethyl ester & 330540 & 360260 & 116462 \\
\hline Benzeneacetic acid, ethyl ester & $\operatorname{ttd}$ & 115060 & 222765 \\
\hline Acetic acid, phenylmethyl ester & 96001 & ttd & 65387 \\
\hline Acetic acid, 2-phenylethyl ester & 1214132 & 1918466 & 873769 \\
\hline Ethyl benzoylformate & 160045 & 214696 & 31274 \\
\hline Benzoic acid, ethyl ester & 49231 & 78092 & $\mathrm{ttd}$ \\
\hline 2-Buten-1-ol, 3-methyl-, acetate & $\mathrm{ttd}$ & $\mathrm{ttd}$ & 96456 \\
\hline Total & 2.164.097 & 3.147.505 & 1.406 .113 \\
\hline KARBONIL & A. Alumunium & A. Besi & A. Tanah liat \\
\hline Butanal, 2-methyl- & ttd & ttd & 120833 \\
\hline Butanal, 3-methyl- & ttd & ttd & 164027 \\
\hline Nonanal & 79972 & 63404 & 692489 \\
\hline 2-Butenal, 2-methyl & $\operatorname{ttd}$ & ttd & 23575 \\
\hline Benzaldehyde & 6635458 & 8480942 & 5255242 \\
\hline $\begin{array}{l}\text { 2-Furancarboxaldehyde, } \\
\text { 5-methyl- }\end{array}$ & 97467 & 162835 & 68713 \\
\hline Benzeneacetaldehyde & 3412965 & 5394463 & 2443836 \\
\hline Cinnamaldehyde, .beta.-methyl- & 922975 & 1287382 & 502456 \\
\hline 1H-Pyrrole-2-carboxaldehyde & 117951 & 191583 & 58168 \\
\hline 5-Methyl-2-phenyl-2-hexenal & 154154 & 352612 & ttd \\
\hline Total & 11.420 .942 & 15.933.221 & 9.329.339 \\
\hline \multicolumn{4}{|l|}{ FENOL } \\
\hline Oxime-, methoxy-phenyl- & 386058 & 591482 & 584478 \\
\hline Phenol & 117841 & 286226 & 121502 \\
\hline Total & 503.899 & 877.708 & 705.980 \\
\hline \multicolumn{4}{|l|}{ ALKOHOL } \\
\hline 1-Butanol, 3-methyl-, acetate & $\operatorname{ttd}$ & $\mathrm{ttd}$ & 822483 \\
\hline 1-Pentanol & 1323660 & 1428555 & 2004790 \\
\hline 2-Heptanol & 1395240 & 1469372 & 1288641 \\
\hline Linalool oxide & 1228736 & 913290 & 843637 \\
\hline 2,3-Butanediol & 1970146 & $\mathrm{ttd}$ & ttd \\
\hline 2,3-Butanediol, [R-( $\left.\left.\mathrm{R}^{*}, \mathrm{R}^{*}\right)\right]-$ & $\operatorname{ttd}$ & ttd & 1111781 \\
\hline 1,6-Octadien-3-ol, 3,7-dimethyl- & 1023258 & 1063917 & 703797 \\
\hline
\end{tabular}

1-Pentanol, 3-methyl-

2-Furanmethanol

2-Furanmethanol, 5-methyl-

4,5-Octanediol, 2,7-dimethyl

Benzyl Alcohol

Phenylethyl Alcohol

Maltol

Ethanol, 2-phenoxy-

Total

KETON

2-Heptanone

2-Butanone, 3-hydroxy-

2,3-Butanedione

2-Cyclohexen-1-one, 3-methyl-

Butyrolactone

Acetophenone

Cyclohexanone, 4-methyl-

2-Cyclopenten-1-one, 3,4,4

trimethyl-

Ethanone, 1-(1H-pyrrol-2-yl)-

Pyranone

Total HIDROKARBON

Nonane, 4,5-dimethyl-

Undecane

Dodecane

Tridecane

Tetradecane

\section{Total
MONOTERPEN \\ HIDROKARBON}

Naphthalene

Azulene

$\begin{array}{cc} & \text { Total } \\ \text { BENZENOID } \\ \text { HIDROKARBON } \\ \text {.beta.-Myrcene } \\ \text { Total } \\ \text { Furaneol } & \\ & \text { FURAN } \\ & \text { Total } \\ & \text { ASAM }\end{array}$

Acetic Acid

Propanoic Acid, 2-methyl-

Pentanoic Acid, 4-methyl-

Hexanoic Acid

Octanoic Acid

Total

SULFUR

Disulfide, dimethyl

Total

TOLUENE

Toluene

p-Xylene

Total

BENZENE

Benzonitrile

Total

FULFURAL

Fulfural

Total

\section{ISOCOUMARIN}

Isocoumarin

Total

Ket: $*$ ttd $=$ tidak teridentifikas

$\begin{array}{rrr}188349 & 328794 & 144504 \\ 920048 & 1346661 & 480383 \\ 55764 & 107113 & \mathrm{ttd} \\ 86643 & \mathrm{ttd} & \mathrm{ttd} \\ 1181806 & 1298159 & 535761 \\ 5824272 & 9561750 & 3557822 \\ 27982 & 55345 & \mathrm{ttd} \\ 145065 & \mathrm{ttd} & 44429 \\ \mathbf{1 5 . 3 7 0 . 9 6 9} & \mathbf{1 7 . 5 7 2 . 9 5 6} & \mathbf{1 1 . 5 3 8 . 0 2 8}\end{array}$

435863

2033308

55055

222039

759079

ttd

ttd

388267

869170

1489860

6.252.641

441170

2979995

30933

295054

ttd

ttd

46433

755569

1273451

2015590

7.838.195

2507
11001

6363590

8197149

687729

$\mathbf{1 5 . 2 6 1 . 9 7 6}$

ttd

3334

5146564

7155857

ttd

12.305.755

483450

3391417

ttd

146578

608620

255169

ttd

314986

324333

425103

5.949.656

ttd

3643898

38761

ttd

3.699.467

ttd

744854

1255153

1224722

1.255.153

1.224.722

$\mathbf{7 4 4 . 8 5 4}$

A. Alumunium

A. Besi

207814

302679

302.679

A. Tanah liat

207.814

ttd

ttd

214503

348762

54827

214.503

348.762

$\mathbf{5 4 . 8 2 7}$

74112499

76713242

63518050

7556424

ttd

303972

532908

448537

348586

75.442.530

941725

79.219 .646

71.378.446

$48058 \quad 82366$

48.058 $\quad 82.366$

99490

99.490

$213020 \quad 4490171$

171105

18896

4.490 .171

ttd
$\mathbf{1 7 1 . 1 0 5}$

231.916

382433

212798

$\mathbf{2 6 5 . 8 6 2} \quad \mathbf{3 8 2 . 4 3 3}$

212.798

ttd $1062303 \quad$ ttd

ttd $\quad \mathbf{1 . 0 6 2 . 3 0 3}$

ttd

ttd $4207 \quad t t d$

$\begin{array}{lll}\text { ttd } & 4.207 & \text { ttd }\end{array}$ 
Penyangraian dengan menggunakan alat sangrai dari alumunium memerlukan waktu 90 menit dengan suhu akhir di permukaan bahan sebesar $86,1^{\circ} \mathrm{C}$, selanjutnya diikuti dengan penyangraian menggunakan alat sangrai dari besi yaitu 70 menit dengan suhu akhir di permukaan bahan sebesar $100,5^{\circ} \mathrm{C}$ dan waktu tercepat dalam penyangraian diperoleh dengan menggunakan alat sangrai dari tanah liat yaitu 50 menit dengan suhu akhir di permukaan bahan sebesar $104,4^{\circ} \mathrm{C}$. Hasil ini diperjelas oleh Jinap dkk. (1998) yang mengatakan bahwa jumlah total dari komponen-komponen senyawa volatil yang bervariasi tergantung pada derajat suhu penyangraian dan waktu.

\section{Hasil Uji Sensoris Cokelat Batang}

Atribut aroma cokelat. Berdasarkan hasil analisis statistik pada faktor perlakuan perendaman dan tanpa perendaman biji kakao kering dan hasil analisis statistik pada faktor penggunaan berbagai jenis bahan alat sangrai yang terlihat pada Tabel 4 (a), menunjukkan bahwa kedua faktor perlakuan tersebut tidak memberikan pengaruh yang berbeda nyata. Namun pada cokelat batang yang dihasilkan dengan perlakuan perendaman biji kakao kering memberikan skor yang lebih tinggi dibandingkan dengan cokelat batang tanpa perendaman. Perlakuan perendaman pada biji kakao kering dengan air memungkinkan kotoran maupun bau-bau seperti bau tanah, jamur ataupun kontaminasi bau lainnya pada biji dapat hilang ataupun tercuci dengan air sehingga kondisi tersebut dapat memberikan pengaruh pada peningkatan kualitas produk akhir khususnya atribut aroma cokelat batang.

Atribut rasa asam, sepat dan pahit. Berdasarkan hasil analisis statistik pada faktor perlakuan perendaman dan tanpa perendaman biji kakao kering, bahwa perlakuan tersebut memberikan pengaruh yang berbeda nyata terhadap atribut

Tabel 4. Hasil analisis sensoris atribut aroma cokelat (a) rasa asam (b), sepat (c) dan pahit (d) dengan perlakuan perendaman dan tanpa perendaman biji kakao kering serta penggunaan berbagai jenis bahan alat sangrai

\begin{tabular}{|c|c|c|c|c|}
\hline \multicolumn{5}{|c|}{ Aroma cokelat } \\
\hline \multirow{2}{*}{ Perlakuan } & \multicolumn{3}{|c|}{ Bahan alat sangrai } & \multirow{2}{*}{ Rata-rata statistik } \\
\hline & Alumunium (Al) & Besi (Be) & Tanah liat (Tl) & \\
\hline Perendaman (P) & $4,73 \pm 1,03^{\text {bcd }}$ & $5,60 \pm 1,12^{\mathrm{ab}}$ & $5,27 \pm 1,71^{\mathrm{abc}}$ & $5,20 \pm 1,34^{x}$ \\
\hline Tanpa perendaman (TP) & $4,27 \pm 1,03^{\mathrm{d}}$ & $5,80 \pm 0,86^{\mathrm{a}}$ & $4,60 \pm 1,18^{\mathrm{cd}}$ & $4,89 \pm 1,21^{\mathrm{x}}$ \\
\hline Rata-rata statistik & $4,50 \pm 1,04^{1}$ & $5,70 \pm 0,99^{k}$ & $4,93 \pm 1,48^{1}$ & \\
\hline \multicolumn{5}{|c|}{ Rasa asam } \\
\hline \multirow{2}{*}{ Biji kakao } & \multicolumn{3}{|c|}{ Bahan alat sangrai } & \multirow{2}{*}{ Rata-rata statistik } \\
\hline & Alumunium (Al) & $\operatorname{Besi}(\mathrm{Be})$ & Tanah liat $(\mathrm{Tl})$ & \\
\hline Perendaman $(\mathrm{P})$ & $3,07 \pm 0,80^{\mathrm{c}}$ & $4,13 \pm 1,35^{\mathrm{ab}}$ & $3,40 \pm 1,12^{\mathrm{bc}}$ & $3,53 \pm 1,18^{x}$ \\
\hline Tanpa perendaman (TP) & $4,07 \pm 0,88^{\mathrm{ab}}$ & $4,47 \pm 1,24^{\mathrm{a}}$ & $3,87 \pm 1,19^{\mathrm{abc}}$ & $4,13 \pm 1,12^{\mathrm{y}}$ \\
\hline Rata-rata statistik & $3,57 \pm 0,97^{1}$ & $4,30 \pm 1,29^{k}$ & $3,63 \pm 1,16^{1}$ & \\
\hline \multicolumn{5}{|c|}{ Rasa sepat } \\
\hline \multirow{2}{*}{ Biji kakao } & \multicolumn{3}{|c|}{ Bahan alat sangrai } & \multirow{2}{*}{ Rata-rata statistik } \\
\hline & Alumunium (Al) & Besi $(\mathrm{Be})$ & Tanah liat $(\mathrm{Tl})$ & \\
\hline Perendaman $(\mathrm{P})$ & $3,80 \pm 1,08^{b}$ & $4,67 \pm 0,90^{\mathrm{a}}$ & $4,40 \pm 1,30^{\mathrm{ab}}$ & $4,29 \pm 1,14^{x}$ \\
\hline Tanpa perendaman (TP) & $4,00 \pm 0,84^{\mathrm{ab}}$ & $4,73 \pm 1,16^{\mathrm{a}}$ & $3,73 \pm 1,10^{\mathrm{b}}$ & $4,15 \pm 1,11^{\mathrm{x}}$ \\
\hline Rata-rata statistik & $3,90 \pm 0,96^{1}$ & $4,70 \pm 1,02^{\mathrm{k}}$ & $4,07 \pm 1,23^{1}$ & \\
\hline \multicolumn{5}{|c|}{ Rasa pahit } \\
\hline \multirow{2}{*}{ Biji Kakao } & \multicolumn{3}{|c|}{ Bahan alat sangrai } & \multirow{2}{*}{ Rata-rata statistik } \\
\hline & Alumunium (Al) & Besi $(\mathrm{Be})$ & Tanah liat $(\mathrm{Tl})$ & \\
\hline Perendaman $(\mathrm{P})$ & $3,53 \pm 0,74^{\mathrm{b}}$ & $4,47 \pm 1,30^{\mathrm{a}}$ & $4,40 \pm 1,30^{\mathrm{ab}}$ & $4,09 \pm 1,04^{\mathrm{x}}$ \\
\hline Tanpa perendaman (TP) & $4,67 \pm 0,90^{\mathrm{a}}$ & $4,80 \pm 1,15^{\mathrm{a}}$ & $4,47 \pm 1,12^{\mathrm{a}}$ & $4,64 \pm 1,05^{\mathrm{y}}$ \\
\hline Rata-rata statistik & $4,10 \pm 0,99^{k}$ & $4,63 \pm 1,22^{\mathrm{k}}$ & $4,37 \pm 0,96^{\mathrm{k}}$ & \\
\hline
\end{tabular}

\section{Keterangan :}

- Huruf superskrip yang sama pada baris yang sama menyatakan tidak beda nyata pada tingkat signifikansi $95 \%$.

- Pada rata-rata statistik, huruf superskrip yang sama pada kolom yang sama dan pada baris yang sama menyatakan tidak beda nyata pada tingkat signifikansi $95 \%$. 
rasa asam cokelat batang. Cokelat batang yang dihasilkan dari biji kakao kering dengan perlakuan perendaman memiliki rasa asam dengan kriteria lemah (skor rata-rata 3) dibandingkan dengan cokelat batang yang dihasilkan dari biji kakao kering tanpa perlakuan perendaman (skor rata-rata 4). Tujuan dari perlakuan perendaman adalah menghentikan proses fermentasi, mengurangi kadar asam laktat hasil fermentasi sehingga nilai $\mathrm{pH}$ dari biji kakao kering dapat naik, membersihkan kotoran-kotoran yang masih menempel pada biji kakao kering fermentasi dan meningkatkan jumlah biji bulat dengan ketampakan yang menarik dengan warna coklat cerah (Poedjiwidodo, 1996). Sedangkan pada faktor perlakuan penggunaan berbagai jenis bahan alat sangrai, tidak memberikan pengaruh yang berbeda nyata terhadap atribut rasa asam.

Hasil analisis statistik pada faktor perlakuan perendaman dan tanpa perendaman biji kakao kering serta faktor penggunaan berbagai jenis bahan alat sangrai, menunjukkan bahwa kedua faktor perlakuan tersebut tidak memberikan pengaruh yang berbeda nyata terhadap atribut rasa sepat cokelat batang yang dihasilkan. Sedangkan untuk atribut rasa pahit, hasil analisis statistik menunjukkan bahwa faktor perlakuan perendaman dan tanpa perendaman biji kakao kering memberikan pengaruh yang berbeda nyata. Namun, pada faktor penggunaan berbagai jenis bahan alat sangrai tidak memberikan pengaruh yang berbeda nyata. Secara keseluruhan rasa sepat dan pahit yang dihasilkan dari cokelat batang pada penelitian ini, disukai oleh para panelis. Skor dari analisis sensoris yang diberikan pada rasa sepat dan pahit berkisar antara 3-4 dengan kriteria memiliki rasa sepat yang lemah dan rasa pahit yang agak lemah. Umumnya rasa sepat dan pahit sangat dipengaruhi oleh kandungan polifenol yang terdapat didalam cokelat batang tersebut. Terlebih lagi tanin atau polifenol dalam cokelat sebagai komponen yang banyak bertanggung jawab terhadap rasa sepat, juga menghasilkan rasa pahit (Misnawi dan Jinap 2008). Supriyanto dkk. (2006) menambahkan bahwa selama penyangraian berlangsung, polifenol akan mengalami kerusakan, sehingga rasa sepat dan pahit akan berkurang, dipercepat oleh panas.

\section{Tingkat Kesukaan}

Hasil analisis tingkat kesukaan cokelat batang menunjukkan bahwa perlakuan perendaman dan tanpa perendaman biji kakao kering serta penggunaan berbagai jenis bahan alat sangrai memberikan pengaruh yang berbeda terhadap atribut aroma cokelat serta atribut rasa asam, sepat dan pahit pada cokelat batang yang dihasilkan. Panelis lebih menyukai cokelat batang dengan perlakuan perendaman biji kakao kering dan penggunaan alat sangrai yang terbuat dari tanah liat. Hal tersebut diduga karena dengan perlakuan perendaman dapat mengurangi kandungan asam-asam pada biji kakao kering yang berlebihan serta memberikan kualitas produk akhir berupa cokelat batang yang sangat baik khususnya dilihat pada atribut aroma.

Selain itu, penggunaan alat sangrai yang terbuat dari tanah liat memberikan panas yang cukup tinggi dengan waktu yang lebih cepat dibandingkan dengan perlakuan penggunaan alat sangrai yang terbuat dari alumunium dan besi. Panas yang tinggi dan waktu penyangraian yang cepat memungkinkan rasa asam, sepat dan pahit pada biji kakao yang disebabkan karena asam-asam organik dan polifenol akan semakin berkurang. Dilihat dari senyawa volatil yang dihasilkan biji kakao sangrai menggunakan alat sangrai dari tanah liat, senyawa dimethylpyrazine, terutama 2,5-dimethylpyrazine yang merupakan salah satu flavour yang tidak dikehendaki pada produk kakao, memiliki luas area yang sangat kecil bila dibandingkan dengan luas area yang dihasilkan oleh penggunaan alat sangrai dari alumunium dan besi. Pada hasil profil senyawa volatil untuk golongan asam khususnya asam asetat, biji kakao sangrai yang dihasilkan menggunakan alat sangrai dari tanah liat memiliki kadar keasaman yang lebih rendah. Kadar asam asetat yang terkandung dalam biji kakao sangrai dengan penggunaan alat sangrai dari tanah liat memiliki konsentrasi sebesar 265,5560 ppb, sedangkan alumunium sebesar 543,7658 ppb dan besi sebesar 312,5714 ppb.

\section{KESIMPULAN}

Biji kakao kering yang disangrai menggunakan alat sangrai dari tanah liat untuk mencapai kadar air $2-3,5 \%$ memerlukan waktu lebih cepat yaitu 50 menit sedangkan alat sangrai dari alumunium 90 menit dan besi 70 menit. Biji sangrai yang dihasilkan dengan perlakuan perendaman, memberikan nilai L* yang lebih rendah (gelap) dibandingkan tanpa perendaman serta perubahan/perbedaan nilai $\mathrm{E}$ yang terjadi adalah kecil $(1,0-3,0)$. Biji sangrai yang disangrai dengan alat sangrai alumunium menghasilkan 63 senyawa dengan total luas area yang lebih besar dibandingkan alat sangrai besi dan tanah liat yang menghasilkan 58 senyawa. Cokelat batang yang dihasilkan dengan perlakuan perendaman biji kakao kering dan penyangraian menggunakan alat sangrai tanah liat lebih disukai oleh panelis karena menghasilkan cokelat batang dengan aroma cokelat yang kuat dan rasa asam yang lemah.

\section{DAFTAR PUSTAKA}

Afoakwa, E.O., Paterson, A., M. Fowler, M. dan Ryan, A. (2009). Matrix effects of flavour volatiles release in dark chocolates varying in particle size distribution and fat content using GC-mass spectrometry and GColfactometry. Food Chemistry 113(1): 208-215. 
Apriyanto. (1989). Analisis Pangan. IPB Press, Bogor .

Febrianto, N.A. (2009). Identifikasi dan Analisa Komponen Aroma pada Lemak Kakao Hasil Refermentasi dengan Metode SPME-GC (Solid Phase Microextraction-Gas Chromatography). Skripsi Sarjana Teknologi Pertanian. Fakultas Teknologi Pertanian. Institut Pertanian Bogor, Bogor.

Misnawi., Jinap, S., Jamilah, B. dan Nazamid, S. (2004). Sensory properties of cocoa liquor as affected by polyphenol concentration and duration of roasting. Food Quality and Preference 15: 403-409.

Misnawi dan Jinap, S. (2008). Cita Rasa, Tekstur, dan Warna Cokelat. Penebar Swadaya, Jakarta.

Nadlirah, U. (2007). Pengaruh Perendaman dengan Larutan $\mathrm{NaHCO}_{3}$ terhadap pH, Cita Rasa, Aroma dan Warna Biji Kakao Fermentasi Varietas Trinitario. Skripsi Sarjana Sains. Fakultas Matematika dan Ilmu Pengetahuan Alam. Universitas Andalas, Padang.

Nanti, M. (2008). Flavour khas pada kakao. Jurnal Industri Hasil Perkebunan 1: 33-36.

Poedjiwidodo, M.S. (1996). Sambung Samping Kakao. Trubus Agriwidya, Jawa Tengah.

Purwandaru, F.Z. (2013). Pengembangan Proses dan Prototipe Alat Pembuatan Cokelat Batang dari Biji Kakao Kering Fermentasi. Skripsi Sarjana Sains. Fakultas Teknologi Pertanian. Universitas Gadjah Mada, Yogyakarta.
Risfaheri, Sumangat, D., Yuningsih, Y. dan Mulyawanti, I. (2003). Pengaruh Perlakuan Perendaman dan Asam Sitrat terhadap Karakteristik Mutu Lada Putih yang Diolah secara Mekanis. Balai Besar Penelitian dan Pengembangan Pascapanen Pertanian. Universitas Juanda. Ciawi, Bogor.

Rohmi, Andriani dan Bambang. (2013). The influence of roasting media variation to the quality of black rice tea (Oryza sativa L.japonica) as an alternative of functional beverage. Jurnal Teknosains Pangan 3: 105-111.

Setiavani, G. (2012). Teknologi pengolahan kakao. http:// verarbeitung 2012.wordpress.com. [3 Januari 2013].

Jinap, S., Rosli, W.I.W., Russly, A.R. dan Nordin, L.M. (1998). Effect of roasting time and temperature on volatile component profiles during nib roasting of cocoa beans (Theobroma cacao). Journal of The Science of Food and Agriculture 77: 441-448.

Supriyanto, Haryadi, Rahardjo, B. dan Marseno, D.W. (2006). Aktivitas antioksidan ekstrak polifenol kasar dari kakao hasil penyangraian menggunakan energi gelombang mikro. Jurnal Teknologi dan Industri Pangan 3: 176182. 